\author{
KLAPCHUK VOLODYMYR, \\ Vasyl Stefanyk Precarpathian National University (Ivano-Frankivsk, Ukraine) \\ e-mail: volodymyr klapchuk@ukr.net, ORCID 0000-0003-1788-794X
}

KLAPCHUK MYKHAILO,

Ivan Franko National University of Lviv (Lviv, Ukraine)

e-mail:m_klapchuk@ukr.net, ORCID0000-0002-8835-7674

POZDNIAKOV OLEKSANDR,

Vasyl Stefanyk Precarpathian National University (Ivano-Frankivsk, Ukraine)

e-mail: dietrich_910@ukr.net,ORCID0000-0001-7525-7108

NOVOSOLOV OLEKSANDR,

Vasyl Stefanyk Precarpathian National University (Ivano-Frankivsk, Ukraine)

e-mail: novo_a@ukr.net, ORCID 0000-0002-1407-4508

\title{
ADMINISTRATIVE-TERRITORIAL DIVISION AND POPULATION DYNAMICS IN GALICIA DURING THE SECOND HALF OF THE 19th CENTURY - THE FIRST THIRD OF THE 20th CENTURY
}

\begin{abstract}
The study consists of two parts: the administrative-territorial division of Galicia and the general description of its population. The first part of the study provides information on the administrative subordination of Galicia during the $14^{\text {th }}$ century - the first third of the $20^{\text {th }}$ century. Detailed information is given on administrative-territorial division of Galicia in the days of Austria, Austria-Hungary, the West Ukrainian People's Republic, the Ukrainian People's Republic, and interwar Poland before the Second World War. The system of administration as well as territorial boundaries of voivodeships and powiats is described. The second part of the study contains quantitative and qualitative data on the total population of Galicia, its ethnic and religious groups.
\end{abstract}

Key words: Galicia; circle; district; voivodeship; powiat; administrative-territorial division; ethnic groups; religious groups.

\section{Introduction}

Administrative-territorial division reflects the influence of state authorities on their subordinated territories. A network of administrative units at different levels is set up due to this influence. Galicia was the largest historical region that has been a part of twelve different states throughout its existence. Thus, it is the most illustrative region of both Ukraine and Europe whose administrative division has retained numerous influences of various forms of governance having acquired its specific features. Therefore, this study is scientifically and practically relevant.

The main purpose of this research is to provide detailed information on the administrative-territorial division of Galicia as well as its multifaceted ethnic, social, religious picture of life from the $16^{\text {th }}$ century to the beginning of the Second World War. A number of issues covered in the study require using a broad retrospective approach and non-standard methodological solutions.

The source base of the research is cartographic materials and statistical data showing the administrativeterritorial division and population movements in Galicia during the above-mentioned period. Important statistical information is contained in census data collections. The population censuses of 1921 and 1931 were conducted by the Polish government in modern Ivano-Frankivsk, Lviv,
Ternopil oblasts, partly in Volyn and Rivne oblasts of Ukraine, in Lesser Poland and Subcarpathian voivodeships of the Republic of Poland (Drugi powszechny spis ludności z dn. 9.XII 1931 r., Zeszyt 58, 64-65, 68, 78, 88; Skorowidz miejscowości Rzeczypospolitej Polskiej..., Mud.12, 1924). The analysis of these data makes it possible to find out the specific features of forming ethnic, cultural, and religious self-identification of Galicia's population. A lot of statistical information is contained in annual statistical bulletins, population censuses, research papers of Polish scientists (Krzyżanowski, and Kumaniecki, 1915; Schukz, 1878; Zamorski, 1989).

\section{Methods}

The historical process of forming territorial structure and development patterns of settlements in Galicia during the $14^{\text {th }}$ century - the first third of the $20^{\text {th }}$ century has been reproduced using historical-genetic method. By means of comparative method, the peculiarities of social relations in the territorial structure of the region have been found out. Through statistical methods, the population dynamics of the region during the above-mentioned period has been shown. The use of cartographic method has made it possible to find out qualitative and quantitative features of the territory at different stages of its historical development. 


\section{Results}

Administrative-territorial division. During its centuries-old history Galicia was both a sovereign state and a part of various administrative associations: the Principality of Halych (1084-1199); the Kingdom of Galicia-Volhynia (1199-1349); the Kingdom of Hungary (1349-1387); the Kingdom of Poland (1387-1569); the Polish-Lithuanian Commonwealth (1569-1772); the Kingdom of Galicia and Lodomeria within the Habsburg Empire (1772-1804), the Austrian Empire (1804-1867); the Austro-Hungarian Empire (1867-1918); the West Ukrainian People's Republic (1918-1919); the Ukrainian People's Republic (1919); the Republic of Poland (1919-1939).

For a short time in 1340, then in 1349, the Polish King Casimir III the Great conquered Galicia, a part of Volhynia, Przemyњl and Sanok. After the Polish-Lithuanian War Poland gained control over Galicia, Belz and Cheim Land, Volyn fell to Lithuania. In 1370, Galicia fell under the jurisdiction of Hungarian voivodes. In 1387, after the military campaign of the Polish Queen Jadwiga, the territory was conquered by the Polish crown. Galicia was divided into Halych, Lviv, Przemyњl, Sanok, Cheim, and Belz okrugs, which were administered by royal governors (starostas). In 1434, the Polish King Wiadysiaw II Yagieiio put an end to the autonomy of Galicia and replaced local judicial and administrative authorities with Polish ones. Halych, Lviv, Przemysl, Sanok okrugs were united into the Ruthenian Voivodeship with Lviv as its capital. Belz Voivodeship with Belz as its capital was established in Western Volhynia.

Towards the end of the $18^{\text {th }}$ century, the decline of the Polish Kingdom began. It resulted in three Partitions of Poland. The First Partition was decided on June 5, 1772, when the accredited representatives of Prussia, Austria, and Russia signed the St. Petersburg Convention on partition of the border areas of the Polish-Lithuanian Commonwealth: Prussia took Pomerania, Kuyavia, and a part of Greater Poland (36 thousand km²; 580 thousand people); Austria took Lesser Poland and Galicia (Ruthenian Voivodeship, Belz Voivodeship, western parts of Volhynian Voivodeship and Podole Voivodeship (83 thousand $\mathrm{km}^{2}, 2.65$ million people); Russia took the eastern territories of Belarus embracing Polotsk, Vitebsk, Mstislav, and a part of Livonia (92 thousand $\mathrm{km}^{2}, 1.3$ million people). The Universal of October 16, 1772 abolished Polish government bodies and local authorities. On September 30, 1773 , the Polish Sejm ratified the partition agreement.

In 1773, Galicia was divided into six circles and 59 okrugs. On July 17,1774 , the governor Andr6s Hбdic reduced the number of okrugs to 19. In September 1774, Austrian troops occupied Chernivtsi, Seret, and Suceava. In 1775, the Duchy of Bukovina with a special status was established (10.4 thousand $\mathrm{km}^{2} ; 75$ thousand people).

The law of March 22, 1782 abolished the administrative division into 6 circles and 19 okrugs. The administrative reform was completed. The reform liquidated the previously division into okrugs and increased the number of circles to 18 . The circles were directly administrated by the Province of Lviv (Tokarz, 1909: 31-35). In 1786, the reorganization of city governments continued, local authorities of some ethnic minorities were abolished. In August of the same year, Joseph II abolished the military administration of Bukovina and annexed its territory to Galicia.

After the Second Partition of the Polish-Lithuanian Commonwealth, officially approved by the Sejm in Grodno in 1793, Greater Poland and a part of Mazovia fell to Prussia. Russia gained control over Ukrainian and Belarusian territories outside Galicia. The territory of Galicia remained under the jurisdiction of Austria.
On November 25, 1795, the Polish king abdicated the throne, which led to the Third Partition of Poland. The PolishLithuanian Commonwealth ceased to exist: Austria took Krakyw, Cheim Land, Southern Podlachia, and the socalled "New Galicia", which soon became a battlefield for France, Austria, Prussia, and Russia; Lithuania, Courland, Western Belarus, and Volhynia fell to Russia; Prussia received the territories of Mazovia with Warsaw, a part of Podlachia and Samogitia.

The Kingdom of Galicia and Lodomeria (1810 $77,300 \mathrm{~km}^{2} ; 1912-78,497 \mathrm{~km}^{2}$ ) was established on the territory of Galicia (Krzyżanowski and Kumaniecki, 1915: 2-3; Szulc, 1920: 70). The kingdom was divided into 12 districts (Berezhany, Zhovkva, Zolochiv, Kolomyia, Lviv, Przemyśl, Sambir, Stanyslavov, Stryi, Sanok, Ternopil, and Chortkiv). Lviv became the administrative and political centre of the kingdom. Bukovina with its capital in Chernivtsi remained a separate province of Galicia until 1849 (it later became a separate province of the Austrian Empire).

The Diet of Galicia and Lodomeria was the legislative body of the kingdom. Absolute power was concentrated in the hands of a governor appointed by the Austrian emperor. The Austrian government appointed members of magistrates. All power in villages belonged to possessors and mandataries.

On March 15, 1848, after the "Spring of Nations", the Austrian Emperor Ferdinand I proclaimed a constitution that de jure provided freedom of speech, freedom of press, freedom of assembly, freedom to convoke parliament. Serfdom was abolished in Galicia in April 1848, in Bukovina - in August 1848. It was nearly five months earlier than in other provinces of the Austrian Empire.

New local governments with centralization of power were established at the same time. 17 crown lands were formed. Each crown land was headed by a governor. Starostas, burgomasters, and vogts were subordinate to governors. In 1853, two levels of administrative authorities were established: 16 local starostwos and 176 powiat governments. In 1866 , there were two types of administration: the governmental administration and the self-governmental one, which was established according to the Statute of the Diet of Galicia and Lodomeria of August 12, 1866.

On February 28, 1867, new administrative-territorial division of Galicia was established. Circles were replaced with 74 powiat governments headed by starostas, who were directly subordinate to the Diet of Galicia and Lodomeria in Lviv. A starostwo had its own executive administration, taxation authority, technical government, mining government (embracing 32 powiats), financial administration, customs administration, school council, etc. (Wykaz udzialu Galicyi..., 1873: 17-18).

On the eve of the First World War there were 76 powiats in Galicia. According to other sources, there were 82 powiats (Schukz, 1878).

Before the second half of November 1918, 49 powiats of Galicia with circa 4 million people and a significant part of the territory (circa 40 thousand $\mathrm{km}^{2}$ ) were under the administration of the West Ukrainian People's Republic (Stakhiv, 1959: 55). On January 22, 1919, the West Ukrainian People's Republic united with the Ukrainian People's Republic and was referred to as "the Western Region of the Ukrainian People's Republic". On July 18, 1919 , as a result of the Ukrainian-Polish War, the province ceased to exist and was divided among Poland, Romania, and Czechoslovakia. In December 1920, four new voivodeships were established on the territory of Galicia: 
Krakyw Voivodeship (50 towns and 1,922 villages), Lviv Voivodeship (60 towns and 2,203 villages), Stanyslaviv Voivodeship (29 towns and 905 villages), and Ternopil Voivodeship (35 towns and 1,076 villages) (Pierwszy powszechny spis ludności..., 1927: 5).

On March 14, 1923, the Western Region of the Ukrainian People's Republic was finally liquidated by the Council of Ambassadors of the Entente Powers, and Eastern Galicia (embracing Lviv Voivodeship, Stanyslaviv Voivodeship, and Ternopil Voivodeship) was given autonomy within Poland. During the interwar period, some insignificant organizational changes occurred in the structure of the voivodeships:

- on January 1, 1923, the administrative center of Chesaniv powiat was moved from Chesaniv to Liubachiv, and the district was renamed to Liubachiv powiat;

- on July 1,1925, the administrative centre of Husiatyn powiat was moved to Kopychyntsi, and the district was renamed to Kopychyntsi powiat;

- on April 1, 1929, Pechenizhyn powiat was liquidated, and its territory was annexed to Kolomyia powiat;

- on April 17, 1931, Turka powiat of Stanyslaviv Voivodeship became a part of Lviv Voivodeship;

- on April 1, 1932 Stryzhiv powiat was divided between
Rzeszyw and Krosno powiats; Staryi Sambir powiat became a part of Sambir powiat; Bohorodchany powiat was divided between Nadvirna and Stanyslaviv powiats; Skole powiat became a part of Stryi powiat.

Population. As the boundaries of interwar Galicia were unclear, it was difficult to calculate the size of its population. Therefore, a general analysis of the demographic situation in Galicia has been made for the period after the annexation of its territory by the Austrian monarchy.

In 1776, more than 2.6 million people inhabited Galicia, after 30 years they were already more than 3.5 million, in 1843 - 4.5 million, in 1869 - nearly 5.5 million, in 1880 nearly 6 million, 1910 - more than 8 million (Fig. 1). Between the end of the $18^{\text {th }}$ century and the $1930 \mathrm{~s}$, the population increased by three times, and the number of inhabitants reached more than 8.5 million. There was a positive dynamic of the population growth. The only exception was the period during the First World War. From 1910 to 1921, the number of inhabitants decreased by 0.6 million (that nearly corresponds to the population size of 1900). Despite significant territorial changes, the population density of Galicia increased in parallel to its size: in 1846 - 62 people/ $\mathrm{km}^{2}$; in 1870 - 70 people/km²; in 1897 - 90 people/km²; in 1911 - 103 people/km².

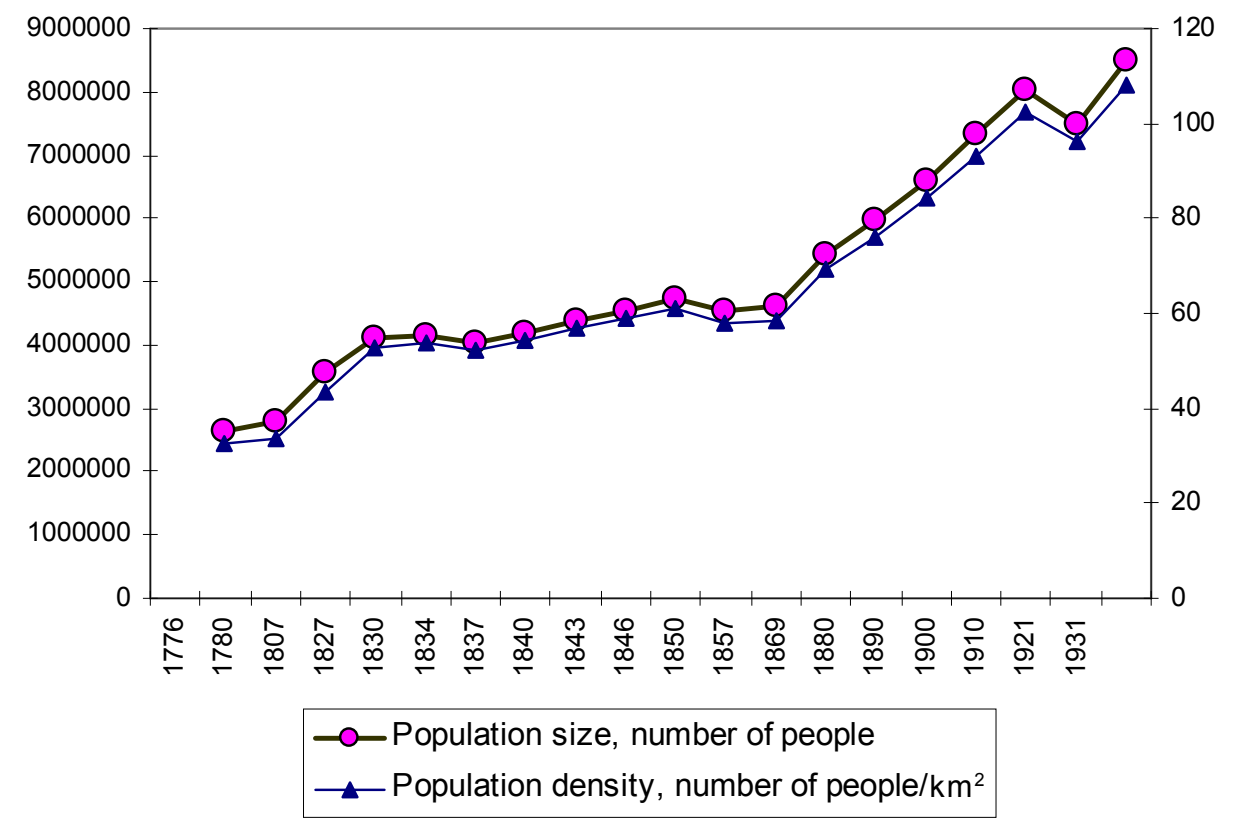

Figure 1. Population size and density in Galicia

The smallest natural population movement took place from 1841 to 1850 (44.9 thousand people), the largest ones (more than 1 million people) - from 1891 to 1900 , from 1901 to 1910 , and from 1921 to 1930 (Fig. 2). There were significant differences in migratory process. The analysis of the period from 1816 to 1931 shows that migration balance was positive only during 40 years (from 1816 to 1830; from 1851 to 1870 ). The largest outflow of population occurred from 1891 to 1920, in particular during and after the First World War. It was caused mainly by the first wave of Ukrainian immigration to America, and the departure of ethnic Germans, Austrians, people of other nationalities, because their countries suffered defeat in the First World War. Only during the first 20 years of the $20^{\text {th }}$ century the negative migration balance was more than 1.16 million people.

Poles and Ukrainians were dominant ethnic groups on the territory of Galicia. From 1880 to 1931 , their number varied between 93 and 98 percent of the total population

ISSN 1728-9343 (Print)

ISSN 2411-3093 (Online)
(Fig. 3) (Drugi powszechny spis ludności z dn. 9.XII 1931 r., Zeszyt 58, 64-65, 68, 78, 88; Skorowidz miejscowości Rzeczypospolitej Polskiej..., 1923-1924; Zamorski, 1989). During the above-mentioned period, the population of Poles increased from 51.5 to 59 percent; at the same time the population of Ukrainians decreased from 43 to 34 percent. Between 1880 and the beginning of the First World War, the population of Germans and Jews decreased from 5.5 to 1.1 percent. The population of Jews reached almost 6.5 percent after the end of the war. The population of other nationalities was nearly 0.1-0.2 percent. Thus, Galicia was mainly a binational state. At the beginning of the $19^{\text {th }}$ century - at the end of the $20^{\text {th }}$ century, Ukrainians were dominant in Eastern Galicia (between 60 and 80 percent), while Poles were dominant in West Galicia (between 70 and 80 percent) (Fig. 4). A significant number of Jews (between 10 and 20 percent) lived in Eastern Galicia (that was twice less than in West Galicia).

SKHID No. 2 (160) March-April 2019 


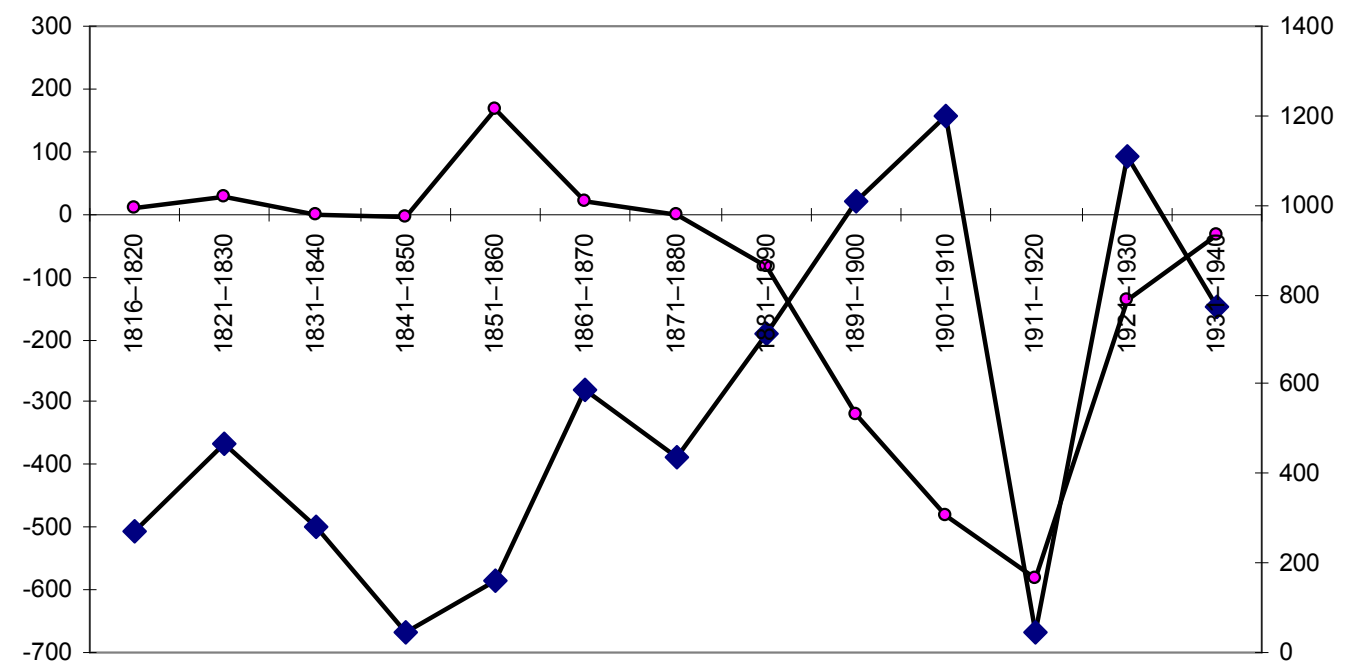

$\rightarrow$ Migratory movements $\rightarrow$ Natural movements

Figure 2. Population movements in Galicia (thousands)

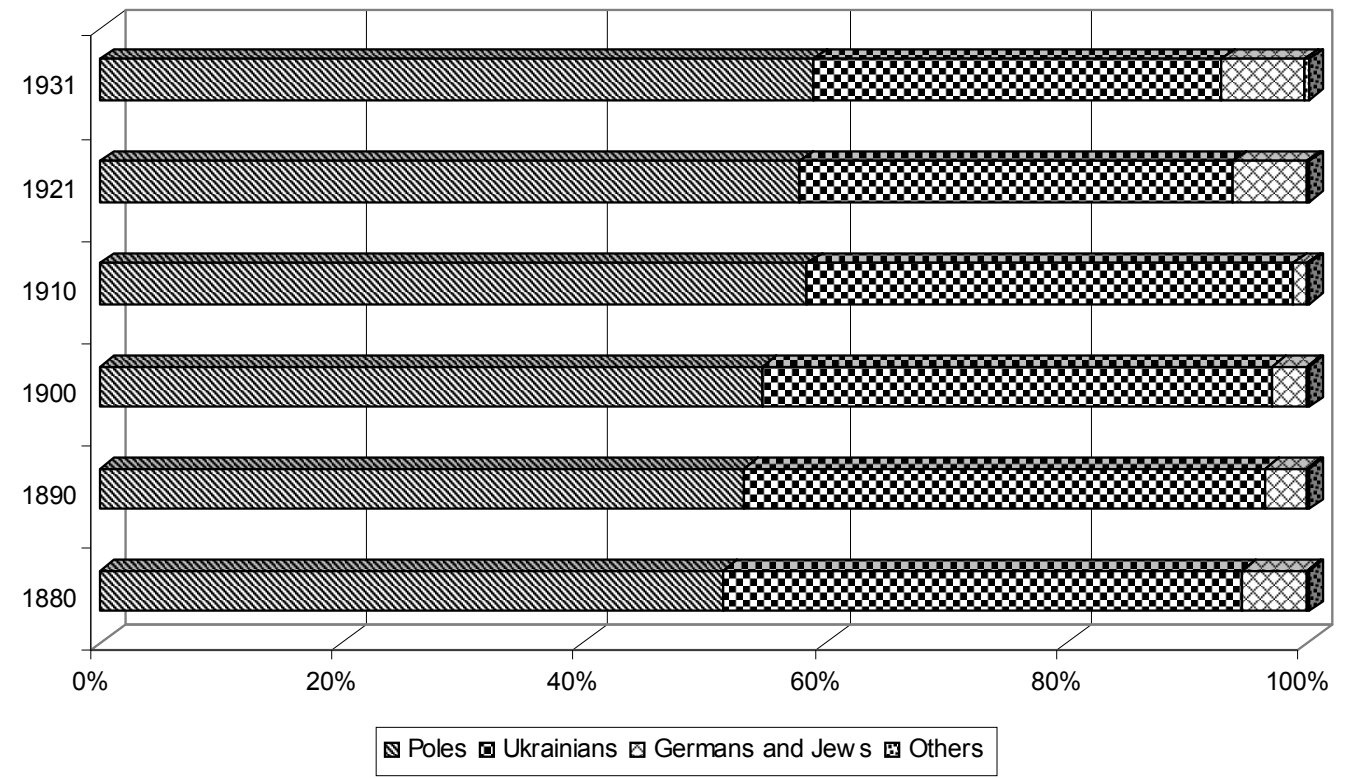

Figure 3. Ethnic groups in Galicia, 1880-1931

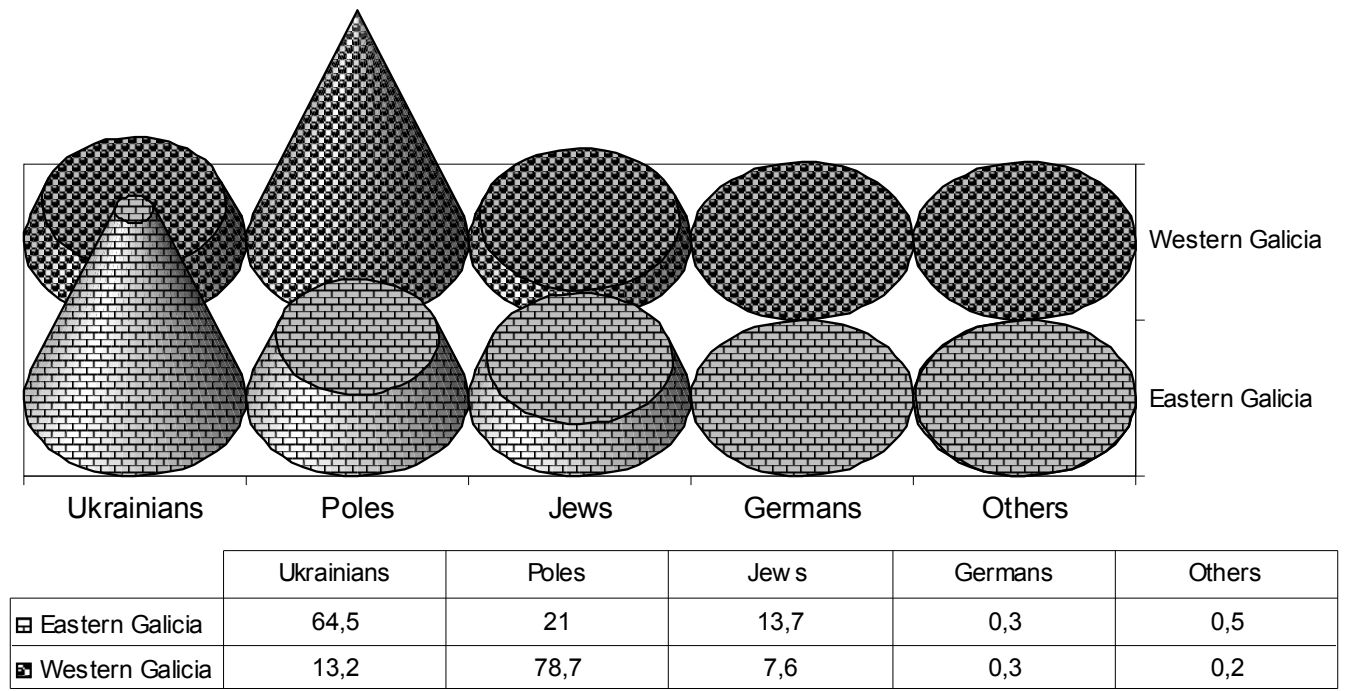

Figure 4. Ethnic groups in Galicia at the beginning of the $20^{\text {th }}$ century, \% 
The religious structure of Galicia was specific. In the middle of the $19^{\text {th }}$ century, the number of Roman Catholics was approximately the same as the population of Greek Catholics (44.74 and 44.89 percent respectively). Before 1931, the number of Roman Catholics increased to 50.8 percent, while the number of Greek Catholics decreased to 39 percent (Fig. 5) (Drugi powszechny spis ludności z dn. 9.XII 1931 r., Zeszyt 58, 64-65, 68, 78, 88; Skorowidz miejscowości Rzeczypospolitej Polskiej..., 1923-1924; Zamorski, 1989). Jews were the third largest religious group. Their population remained stable and ranged between 9 and 11 percent. The number of Evangelists decreased by 40 percent (from 0.7 to 0.4 percent), while the number of Orthodox Christians increased significantly (from 0.03 to 0.28 percent).

Before the First World War, almost all ethnic Ukrainians in Galicia (97-98 percent) were Greek-Catholic and Ukrainian-speaking (Fig. 6). During the interwar period, nearly 10 percent of Ukrainians declared Polish as their native language for the following reasons: polonization of Ukrainian people; impossibility of engaging in business, administrative and political activities for non-Polish citizens, etc.

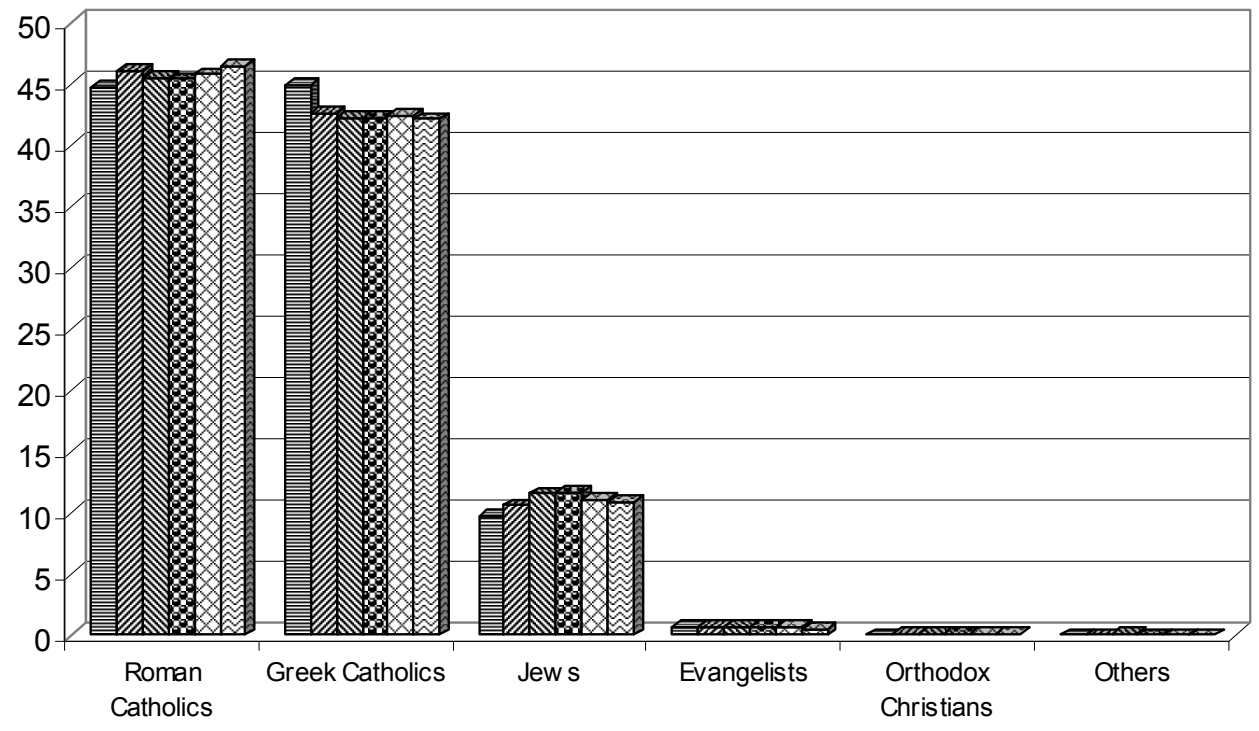

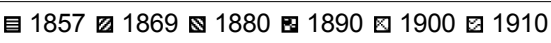

Figure 5. Religious groups in Galicia, \%

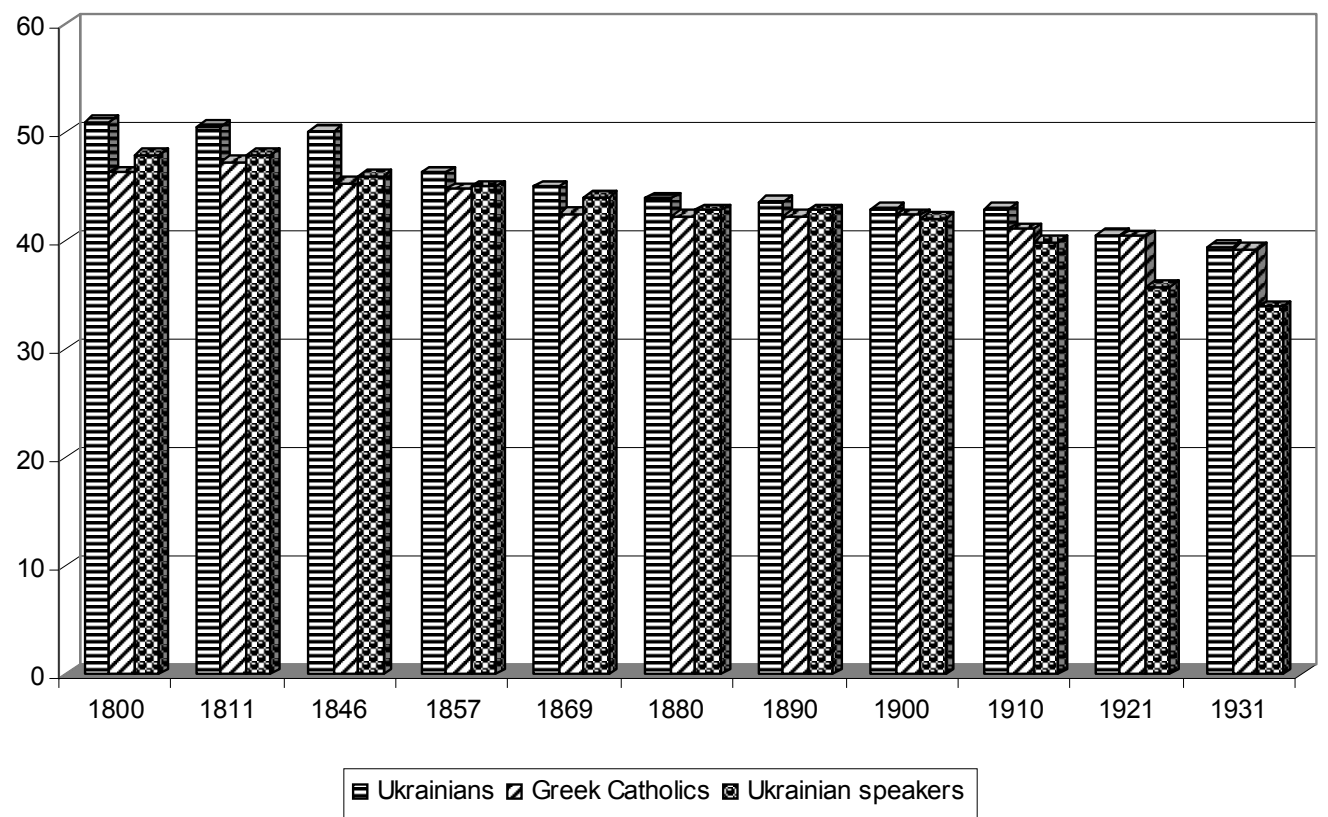

Figure 6. Ukrainian population in Galicia

\section{Discussion}

Strict subordination and systematization of administrative division acquired by Galicia during the Austrian period (1772-1918) has been proved by the authors' ana- lysis of the demographic situation. There was a stable and essential population growth, except for the period between 1914 and 1921, the time of the First World War and the Polish-Ukrainian War. The authors have also 
analyzed migratory movements in Galicia. They show that there has been a positive migration balance for almost one hundred years. This process was interrupted by the First World War that caused the wave of Ukrainian immigration to America, and the departure of ethnic Germans, Austrians and Poles to their historical homelands. The national structure of the population of the region has also been established. The analysis shows an increase in the number of Poles in comparison with other ethnic groups. Thus, certain trends in the religious situation of the region have been found out. These trends were connected with the increasing number of Greek Catholics, Catholics and Jews in Galicia.

\section{Conclusions}

During its centuries-old history Galicia was both a sovereign state and a part of various administrative associations: the Principality of Halych, the Kingdom of Galicia-Volhynia, the Kingdom of Hungary, the Kingdom of Poland, the Polish-Lithuanian Commonwealth, the Habsburg Empire, the Austrian Empire, the Austro-Hungarian Empire, the West Ukrainian People's Republic, the Ukrainian People's Republic, the Republic of Poland.

In 1773, Galicia was divided into six circles and 59 okrugs. In 1774, the number of okrugs was reduced to 19. In 1782, division into okrugs was liquidated, and the number of circles was increased to 18 . The circles were directly administrated by the Province of Lviv. In 1810, the Kingdom of Galicia and Lodomeria was established. The kingdom was divided into 12 districts and its capital was in Lviv. Bukovina remained a separate province of Galicia until 1849. 17 crown lands headed by governors were formed at the same time. Starostas, burgomasters, and vogts were subordinate to governors. In 1853, two levels of administrative authorities were established: 16 local starostwos and 176 powiat governments. In 1867, 74 powiat governments were established. The powiat governments were subordinate to the Diet of Galicia and Lodomeria in Lviv. On the eve of the First World War there were 76 powiats in Galicia. Before the second half of November 1918, 49 powiats of Galicia were under the administration of the West Ukrainian People's Republic. On January 22, 1919, the West Ukrainian People's Republic united with the Ukrainian People's Republic and was referred to as "the Western Region of the Ukrainian People's Republic". On July 18, 1919, the province was liquidated and divided among Poland, Romania, and Czechoslovakia. In December 1920, four new voivodeships were established on the territory of Galicia: Krakyw Voivodeship, Lviv Voivodeship, Stanyslaviv Voivodeship, and Ternopil Voivodeship. On March 14, 1923, the Western Region of the Ukrainian People's Republic was finally liquidated by the Council of Ambassadors of the Entente Powers, and Eastern Galicia (embracing Lviv Voivodeship, Stanyslaviv Voivodeship, and Ternopil Voivodeship) was given autonomy within Poland.

In 1776, more than 2.6 million people inhabited Galicia in 1810 , the population of the region was 3.5 million, in 1843 - 4.5 million, in 1869 - 5.5 million, in 1880 - 6 million, in 1910 - 8 million, in 1939 - 8.5 million. There was a positive dynamic of the population growth. The only exception was the period during the First World War. From 1910 to 1921, the number of inhabitants decreased by 0.6 million (that nearly corresponds to the population size of 1900).

Poles and Ukrainians were dominant ethnic groups on the territory of Galicia. From 1880 to 1931, their number varied between 93 and 98 percent of the total population. The religious structure of Galicia was specific. In the middle of the $19^{\text {th }}$ century, the number of Roman Catholics was approximately the same as the population of Greek Catholics. Before 1931, the number of Roman Catholics increased to 50.8 percent, while the number of Greek Catholics decreased to 39 percent. The population of Jews ranged between 9 and 11 percent.

\section{REFERENCES}

Stakhiv, M. (1959). Zakhidnya Ukrayina. Narys istoriyi derzhavnoho budivnytstva ta zbroynoyi $i$ dyplomatychnoyi oborony $v$ 1918-1923 [Western Ukraine. Studies on the History of State Building, Armed and Diplomatic Defence (1918-1923)], Scranton, Vol. III, pp. 55. (In Ukranian)

Drugi powszechny spis ludności z dn. 9.XII 1931 r. (1937). Mieszkania i gospodarstwa domowe. Ludnośc. Stosunki zawodowe, Warszawa, Seria C, Zeszyt 58, Miasto Lwów, s. 11. (In Polish)

Drugi powszechny spis ludności z dn. 9.XII 1931 r. (1937). Mieszkania i gospodarstwa domowe. Ludnośc. Stosunki zawodowe, Warszawa, 1937, Seria C, Zeszyt 64, Miasto Kraków, s. 11. (In Polish)

Drugi powszechny spis ludności z dn. 9.XII 1931 r. (1938). Mieszkania i gospodarstwa domowe. Ludnośc. Stosunki zawodowe, Warszawa, Seria C, Zeszyt 65, Wojewódstwo Stanisławowskie, s. 22. (In Polish)

Drugi powszechny spis ludności z dn. 9.XII 1931 r. (1938). Mieszkania i gospodarstwa domowe. Ludnośc. Stosunki zawodowe, Warszawa, Seria C, Zeszyt 68, Wojewódstwo Lwowskie bez miasta Lwowa, s. 32. (In Polish)

Drugi powszeczny spis ludności z dn. 9.XII 1931 r. (1938). Mieszkania i gospodarstwa domowe. Ludnośc. Stosunki zawodowe, Warszawa, Seria C, Zeszyt 78, Wojewódstwo Tarnopolskie, s. 26. (In Polish)

Drugi powszeczny spis ludności z dn. 9.XII 1931 r. (1938). Mieszkania i gospodarstwa domowe. Ludnośc. Stosunki zawodowe, Warszawa, Seria C, Zeszyt 88, Wojewódstwo Krakowskie bez miasta Krakowa, s. 26. (In Polish)

Krzyżanowski, A. and Kumaniecki, K. (1915). Statystyka Polski, Kraków, s. 2-3. (In Polish)

Pierwszy powszechny spis ludności Rzeczypospolitej Polskiej z dnia 30 wrzesnia 1921 r. (1927). Warszawa, s. 5. (In Polish)

Schukz, R.A. (1878). General Post- und Strassenkarte des Kronlandea Galizien und Lodomerien mit Auschwitz, Zator und Krakau: so wie des Kronlandes Bukowina, Wien, Artaria \& Co. (In German)

Skorowidz miejscowości Rzeczypospolitej Polskiej opracowany na podstawie wyników pierwszego Powszechnego Spisu Ludności z dn. 30 września 1921 r. i innych źródeł urzędowych (1924). Warszawa, Vol. 12, Województwo Krakowskie, Śląsk Cieszyński, s. 11-12. (In Polish)

Skorowidz miejscowości Rzeczypospolitej Polskiej opracowany na podstawie wyników pierwszego Powszechnego Spisu Ludności z dn. 30 września 1921 r. i innych źródeł urzędowych (1924). Warszawa, Vol. 13, Wojewódstwo Lwowskie, s. 8-9. (In Polish)

Skorowidz miejscowości Rzeczypospolitej Polskiej opracowany na podstawie wyników pierwszego Powszechnego Spisu Ludności z dn. 30 września 1921 r. i innych źródeł urzędowych (1923). Warszawa, Vol. XIV, Wojewódstwo Stanisławowskie, s. 10-11. (In Polish)

Skorowidz miejscowości Rzeczypospolitej Polskiej opracowany na podstawie wyników pierwszego Powszechnego Spisu Ludności z dn. 30 września 1921 r. i innych źródeł urzędowych (1923). Warszawa, T. XV, Wojewódstwo Tarnopolskie, s. 9-10. (In Polish)

Schukz, R. A. (1878). General Post- und Strassenkarte des Kronlandea Galizien und Lodomerien mit Auschwitz, Zator und Krakau: so wie des Kronlandes Bukowina, Wien, Artaria \& Co. 
Szulc, S. (1920). Wartość materiał ów statystycznych dotyczących stanu ludności b. Królestwa Polskiego, Warszawa, s. 70. (In Polish)

Tokarz, W. (1909). Galicya: w poczatkach ery Józefińskiej w świetle ankiety urzędowej z roku 1783, Kraków, s. 31-35. (In Polish)

Wykaz udzialu Galicyi i wielkiego księztwa Krakowskiego na powszechnej wystawie 1873 w Wiedniu (1873), Wieden, Druk. L.K. Zamarskiego, s. 17-18. (In Polish)

Zamorski, K. (1989). Informator Statystyczny do dziejów Społ eczno-Gospodarczych Galicji: Ludność Galicji w latach 1857-1910, Kraków-Warszawa, 1989, s. 70-71, 91-92. (In Polish)

\section{LIST OF REFERENCE LINKS}

Стахів М. Західня Україна. Нарис історії державного будівництва та збройної і дипломатичної оборони в 1918-1923 [Western Ukraine. Studies on the History of State Building, Armed and Diplomatic Defence (1918-1923)], Скрентон, 1959, T. III, c. 55 .

Drugi powszeczny spis ludności z dn. 9.XII 1931 r. Mieszkania i gospodarstwa domowe. Ludnośc. Stosunki zawodowe, Warszawa, 1937, Seria C, Zeszyt 58, Miasto Lwów, s. 11.

Drugi powszeczny spis ludności z dn. 9.XII 1931 r. Mieszkania i gospodarstwa domowe. Ludnośc. Stosunki zawodowe, Warszawa, 1937, Seria C, Zeszyt 64, Miasto Kraków, s. 11.

Drugi powszeczny spis ludności z dn. 9.XII 1931 r. Mieszkania i gospodarstwa domowe. Ludnośc. Stosunki zawodowe, Warszawa, 1938, Seria C, Zeszyt 65, Wojewódstwo Stanisławowskie, s. 22

Drugi powszeczny spis ludności z dn. 9.XII 1931 r. Mieszkania i gospodarstwa domowe. Ludnośc. Stosunki zawodowe, Warszawa, 1938, Seria C, Zeszyt 68, Wojewódstwo Lwowskie bez miasta Lwowa, s. 32

Drugi powszeczny spis ludności z dn. 9.XII 1931 r. Mieszkania i gospodarstwa domowe. Ludnośc. Stosunki zawodowe, Warszawa, 1938, Seria C, Zeszyt 78, Wojewódstwo Tarnopolskie, s. 26 .

Drugi powszeczny spis ludności z dn. 9.XII 1931 r. Mieszkania i gospodarstwa domowe. Ludnośc. Stosunki zawodowe, War- szawa, 1938, Seria C, Zeszyt 88, Wojewódstwo Krakowskie bez miasta Krakowa, s. 26.

Krzyżanowski A., Kumaniecki K. Statystyka Polski, Kraków, 1915, s. 2-3.

Pierwszy powszechny spis ludności Rzeczypospolitej Polskiej z dnia 30 wrzesnia 1921 r., Warszawa, 1927, s. 5.

Schukz R. A. General Post- und Strassenkarte des Kronlandea Galizien und Lodomerien mit Auschwitz, Zator und Krakau: so wie des Kronlandes Bukowina, Wien, Artaria \& Co, 1878.

Skorowidz miejscowości Rzeczypospolitej Polskiej opracowany na podstawie wyników pierwszego Powszechnego Spisu Ludności z dn. 30 września 1921 r. i innych źródeł urzędowych, Warszawa, 1924, T. 12, Województwo Krakowskie, Śląsk Cieszyński, s. 11-12.

Skorowidz miejscowości Rzeczypospolitej Polskiej opracowany na podstawie wyników pierwszego Powszechnego Spisu Ludności z dn. 30 września 1921 r. i innych źródeł urzędowych, Warszawa, 1924, T. XIII, Wojewódstwo Lwowskie, s. 8-9.

Skorowidz miejscowości Rzeczypospolitej Polskiej opracowany na podstawie wyników pierwszego Powszechnego Spisu Ludności z dn. 30 września 1921 r. i innych źródeł urzędowych, Warszawa, 1923, T. XIV, Wojewódstwo Stanisławowskie, s. 10-11.

Skorowidz miejscowości Rzeczypospolitej Polskiej opracowany na podstawie wyników pierwszego Powszechnego Spisu Ludności z dn. 30 września 1921 r. i innych źródeł urzędowych, Warszawa, 1923, T. XV, Wojewódstwo Tarnopolskie, s. 9-10.

Schukz R. A. General Post- und Strassenkarte des Kronlandea Galizien und Lodomerien mit Auschwitz, Zator und Krakau: so wie des Kronlandes Bukowina, Wien, Artaria \& Co, 1878.

Szulc S. Wartość materiałów statystycznych dotyczących stanu ludności b. Królestwa Polskiego, Warszawa, 1920, s. 70.

Tokarz W. Galicya: w początkach ery Józefińskiej w świetle ankiety urzędowej z roku 1783, Kraków, 1909, s. 31-35.

Wykaz udzialu Galicyi i wielkiego księztwa Krakowskiego na powszechnej wystawie 1873 w Wiedniu, Wieden, Druk. L.K. Zamarskiego, 1873, s. 17-18.

Zamorski K. Informator Statystyczny do dziejów SpołecznoGospodarczych Galicji: Ludność Galicji w latach 1857-1910, Kraków-Warszawa, 1989, s. 70-71, 91-92

\section{Клапчук Володимир,}

Прикарпатський національний університет імені Василя Стефаника (м. Івано-Франківськ, Украйна) e-mail: volodymyr_klapchuk@ukr.net, ORCID 0000-0003-1788-794X

Клапчук Михайло,

Львівський наиіональний університет імені Івана Франка (м. Львів, Украӥна)

e-mail: m_klapchuk@ukr.net, ORCID 0000-0002-8835-7674

Поздняков Олександр,

Прикарпатський національний університет імені Василя Стефаника (м. Івано-Франківськ, Украӥна) e-mail: dietrich910@ukr.net, ORCID0000-0001-7525-7108

Новосьолов Олександр,

Прикарпатський наиіональний університет імені Василя Стефаника (м. Івано-Франківськ, Украӥна) e-mail:novo_a@ukr.net, ORCID 0000-0002-1407-4508

\section{АДМІНІСТРАТИВНО-ТЕРИТОРІАЛЬНИЙ ПОДІЛ I ДИНАМІКА ЧИСЕЛЬНОСТІ НАСЕЛЕННЯ ГАЛИЧИНИ ПРОТЯГОМ ДРУГОÏ ПОЛОВИНИ ХІХ cm. - ПЕРШОÏТРЕТИНИ ХХ $\mathrm{cm}$.}

Реконструкція адміністративно-територіального устрою та етнічної, соціальної, релігійної картини життя Галичини в усій його багатогранності до початку Другої світової війни є основним завданням цього дослідження. Низка питань, що розглядаються у статті, потребують застосування широкого ретроспективного підходу до проблеми та нестандартних методологічних рішень. Джерельною базою дослідження є картографічний ма- 
теріал і статистичні дані, що демонструють адміністративно-територіальний поділ і динаміку населення в Галичині. Важлива статистична інформація міститься в матеріалах переписів населення 1921 i 1931 рр., проведених польським урядом у межах сучасних Івано-Франківської, Львівської, Тернопільської, частково Волинської та Рівненської областей України, Малопольському в Підкарпатському воєводствах Республіки Польща. Багато статистичної інформації міститься в щорічних статистичних бюлетенях і наукових роботах польських вчених. Галичина впродовж своєї багатовікової історії була як суверенною державою, так і суб'єктом різних адміністративних утворень: Галицького та Галицько-Волинського князівств, Угорське та Польського королівств, Речі Посполитої, Габсбурзької та Австрійської імперій, Австро-Угорщини Західноукраїнської та Української Народних Республік, Польської Республіки. 1773 р. Галичину поділено на шість циркулів і 59 окру́г; 1774 р. кількість округ зменшилася до 19. 1782 р. ліквідовано інститут окру́г та збільшено кількість циркулів до 18, які безпосередньо підпорядковувалися Львівській губернії. 1810 р. на теренах Галичини утворено Королівство Галичини і Володимирії, яке поділялося на 12 дистриктів 3 адміністративно-політичним центром у м. Львові. До 1849 р. окремим округом Галичини залишалася Буковина. Тоді ж утворено 17 коронних країв на чолі з губернаторами (відтак - намісниками), яким підпорядковувалися повітові старости, бурмістри i війти. 1853 р. запроваджено двоступінчату адміністративну владу: 16 окружних староств і 176 повітових урядів. 1867 р. утворено 74 повітові уряди, що підпорядковувалися Крайовому уряду у Львові. Напередодні Першої світової війни у Галичині було 76 повітів. До другої половини листопада 1918 р. під адмініструванням Західноукраїнської Народної Республіки (ЗУНР) опинилося 49 повітів Галичини. 22 січня 1919 р. ЗУНР об'єдналася з Українською Народною Республікою, отримавши назву "Західна Область Української Народної Республіки" (ЗОУНР), що була ліквідована 18 липня 1919 р. і розділена між Польщею, Румунією і Чехословаччиною. У грудні 1920 р. в межах Галичини утворено чотири нові воєводства: Краківське, Львівське, Станиславівське і Тернопільське. 14 березня 1923 р. Рада Послів держав Антанти остаточно ліквідувало 30 унР, а Східній Галичині (Львівське, Станиславівське та Тернопільське воєводства) надано автономію у складі Польщі. 1776 р. у Галичині проживало понад 2,6 млн осіб, 1810 р. - 3,5, 1843 р. - 4,5, 1869 р. - 5,5, 1880 р. - 6, 1910 р. - 8, 1939 р. - 8,5 млн мешканців. Відбувалася позитивна динаміка чисельності населення, за винятком періоду Першої світової війни, коли його кількість впродовж 1910-1921 рр. зменшилася на 0,6 млн осіб і майже відповідала показнику 1900 р. Панівне місце у національному складі краю складали поляки та українці, чисельність яких упродовж 1880-1931 рр. коливалася у межах 93-98 \%. Оригінальною була релігійна ситуація: якщо у середині XIX ст. чисельність римо-католиків і греко-католиків була приблизно однаковою, то до 1931 р. кількість римо-католиків зросла до 50,8 \%, а греко-католиків зменшилася до 39 \%. Чисельність іудеїв коливалася в межах 9-11\%.

Ключові слова: Галичина; циркул; дистрикт; воєводство; повіт; адміністративно-територіальний устрій; національний склад населення; релігійний склад населення.

(C) Klapchuk Volodymyr, Klapchuk Mykhailo, Pozdniakov Oleksandr, Novosolov Oleksandr

Надійшла до редакції: 11.03.2019

Прийнята до друку: 05.04.2019 